\title{
Ligand-Controlled Copper-Catalyzed Oxidation of Benzylamines with Oxygen
}

\section{Category}

Polymer-Supported Synthesis

\section{Key words}

red copper

benzylamines

oxidation

nitriles

imines<smiles>N#Cc1ccccc1Br</smiles>

$65 \%$ yield<smiles></smiles>

(1 mmol) red copper $(10 \mathrm{mg})$

$\mathrm{NH}_{4} \mathrm{Br}(1 \mathrm{mmol})$

$\underset{\text { PhMe, } 100^{\circ} \mathrm{C}}{\stackrel{\text { isoquinoline }(1.2 \mathrm{mmol})}{\longrightarrow}}$

under $\mathrm{O}_{2}(1 \mathrm{~atm})$

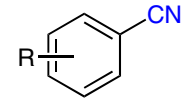

6 examples<smiles>N#Cc1ccc(Br)cc1</smiles><smiles>N#Cc1ccc(Cl)cc1</smiles>

$84 \%$ yield<smiles>Cc1ccc(C#N)cc1</smiles>

$98 \%$ yield<smiles>COc1ccc(C#N)cc1</smiles><smiles>N#Cc1ccc(O)cc1</smiles>

$67 \%$ yield

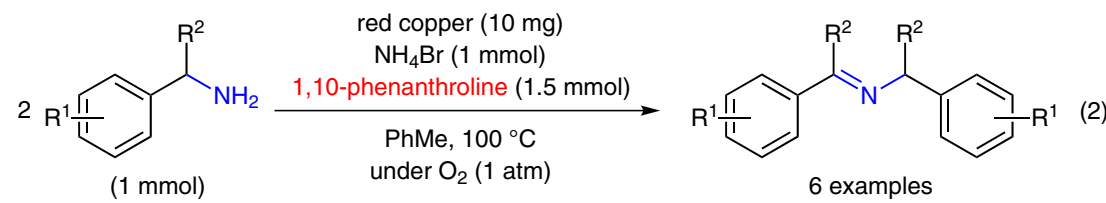<smiles>Brc1ccccc1/C=N/Cc1ccccc1Br</smiles>
$86 \%$ yield<smiles>Cc1ccc(C=NCc2ccc(C)cc2)cc1</smiles>

$>99 \%$ yield<smiles>Brc1ccc(/C=N/Cc2ccc(Br)cc2)cc1</smiles>

$>99 \%$ yield<smiles>COc1ccc(/C=N/Cc2ccc(OC)cc2)cc1</smiles>

$>99 \%$ yield<smiles>Clc1ccc(/C=N/Cc2ccc(Cl)cc2)cc1</smiles>

$>99 \%$ yield<smiles>C/C(=N\C(C)c1ccccc1)c1ccccc1</smiles>

$>99 \%$ yield
Significance: Commercially available red copper catalyzed the oxidation of benzylamines with molecular dioxygen in the presence of isoquinoline or 1,10-phenanthroline to give the corresponding benzonitriles (eq. 1) or dibenzylimines (eq. 2).
Comment: The SEM analyses of the catalyst before and after the reaction showed that the surface of the catalyst was roughened during the reaction to suggest leaching of copper. 